\title{
The effect of different maternal positions on reactivity of the nonstress test, maternal blood pressure and heart rate
}

\section{Farklı maternal pozisyonların nonstres test reaktivitesi, maternal kan basıncı ve kalp atım hızına etkisi}

\author{
Didem KIRATLI ${ }^{1}$, Tülay YAVAN ${ }^{2}$, Kazım Emre KARAŞAHİN ${ }^{3}$, Müfit Cemal YENEN ${ }^{4}$ \\ ${ }^{1}$ Dr. Behçet Uz Çocuk Hastanesi, İzmir, Türkiye \\ ${ }^{2}$ İmir Ekonomi Üniversitesi, Sağlık Bilimleri Fakültesi, İzmir, Türkiye \\ ${ }^{3}$ Sağlık Bilimleri Üniversitesi, Gülhane Ĕ̆̈itim ve Araştırma Hastanesi, Kadın Hastalıkları ve Doğum Kliniği, Ankara, Türkiye \\ ${ }^{4}$ Girne Üniversitesi Dr. Suat Günsel Hastanesi, Kadın Hastalıklarl ve Doğum Klinĭ̆i, Girne, KKTC
}

\section{ABSTRACT}

Objective: We aimed to investigate the effects of different maternal positions on reactivity of the Nonstress Test (NST), maternal blood pressure and heart rate.

Methods: In this experimental study, 243 pregnants were randomized to the position groups (sitting, semi-Fowler's, semi-Fowler's left lateral) at 34-37 and 38-40 gestational weeks. The questionnaire form inquiring socio-demographic and obstetric characteristics and "NST Form" were used. For the statistical comparison of the continuous variables, one-way ANOVA, and independent groups t test were used.

Results: Though not statistically significant difference existed, NST reactivity at sitting position was higher than the other positions, and it was higher in 38-40 gestational weeks relative to 34-37 gestational weeks ( $p>0.05$ ). Results of NST reactivity were evaluated at 4 time periods. Time-to-reactivity in relation to position didn't reveal a significant difference. Independent of the position, we found a significant difference in time to reactivity between $0-5$ and $0-10$ minutes, and between $0-10$ and $0-15$ minutes $(p<0.05)$, but there was no significant difference in time to reactivity between $0-15$ and $0-20$ minutes $(p>0.05)$. Fetal heart rate, maternal systolic, diastolic blood pressure levels were similar in all gestational weeks regardless of the position, at baseline and 10 minutes later $(p>0.05)$. Maternal heart rates were significantly different in semifowler left lateral position $(p<0.05)$.

Conclusion: As the most comfortable positions for the pregnants NST applications at semi-Fowler's left lateral and sitting positions seem to be more appropriate in order to get higher NTS reactivity results. No significant difference was observed in NTS reactivity between applications at 15 and 20 minutes, so application at 15 minutes may be sufficient for NST evaluation.

Keywords: Prenatal diagnosis, cardiotocography (CTG), high-risk pregnancy, NST

$\ddot{\mathbf{O Z Z}}$

Amaç: Farklı maternal pozisyonların Nonstres Test (NST) reaktivitesi, maternal kan basıncı ve kalp atım hızına etkisini incelemeyi amaçladık.

Yöntem: Bu deneysel çalışmada, 34-37 ve 38-40 gestasyonel haftalarda 243 gebe kadın, belirlenen pozisyon gruplarına (oturarak, semifowler, semifowler sol lateral) randomize edildi. Veri toplamak için sosyodemografik ve obstetrik özellikleri içeren anket formu ve "NST Formu" kullanıldı. Sürekli değişkenlerin istatistik karşılaştırmalarında one-way ANOVA ve bağımsız gruplarda t testi kullanıldı.

Bulgular: NST reaktivitesi oturur pozisyonda diğer pozisyonlara göre daha yüksek, 38-40 haftalarda 34-37 haftalara göre daha yüksek bulundu fakat istatistiksel olarak anlamlı bir fark belirlenmedi $(p>0,05)$. Reaktif NST sonuçları 4 zaman diliminde değerlendirildi. Pozisyona göre reaktivite zamanları arasında istatistiksel olarak anlamlı bir fark yoktu. Pozisyondan bağımsız olarak, 0-5 ve $0-10 \mathrm{dk}$.'lar arasında, $0-10$ ve $0-15 \mathrm{dk}$.'lar arasında reaktivite oranı açısından istatistiksel olarak anlamlı fark belirlendi $(p<0,05)$, fakat $0-15$ ve 0-20 dk.'lar arasında reaktivite oranları açısından anlamlı bir fark belirlenmedi $(p>0,05)$. Pozisyondan bağımsız olarak bütün gestasyonel haftalarda bazal fetal kalp hızı, başlangıç ve 10. dk.'da maternal sistolik ve diastolik kan basıncı düzeyleri benzerdi $(p>0,05)$. Maternal kalp atım hızı yarı-Fowler sol lateral pozisyonda önemli derecede farklı idi $(p<0,05)$.

Sonuç: Gebeler açısından daha konforlu görünen ve daha yüksek reaktif sonuçlar görülen yarı-Fowler sol lateral ve oturur pozisyonlar NST uygulaması için daha uygun görünmektedir. 15 ve 20 dk. 'lar arasında reaktivite oranları açısından anlamlı bir fark belirlenmediğinden 15 dk.'lık uygulamanın NST değerlendirmesi için yeterli olabileceği dü̧̈ünülmektedir.

Anahtar kelimeler: Prenatal tanı, kardiotokografi (KTG), yüksek riskli gebelik, NST
Alındığı tarih: 10.01.2018

Kabul tarihi: 11.06 .2018

Yazışma adresi: Prof. Dr. Tülay Yavan, İzmir University of Economics Sakarya Caddesi, No:156, 35330 - Balçova - İzmir - Türkiye e-mail: tulayaykan@hotmail.com 


\section{INTRODUCTION}

Decreasing perinatal morbidity and mortality to minimum is the main objective of the obstetrics and could be possible by antenatal follow-ups ${ }^{(1)}$. Today it is possible -to some extent- to diagnose and treat fetal disease by in utero fetal evaluation. While the early aim has been to prevent and treat maternal diseases, fetal counterpart of this approach is now accepted as equally important. Philosophy of accepting "fetus as a patient" is spreading and fetal rights are spoken of (2).

In 1973, in order to reduce the the number of fetuses lost in utero, fetal heart rate (FHR) monitoring had begun to be used during delivery ${ }^{(3)}$. There are different methods of fetal surveillance, and electronic fetal monitoring (EFM) has become the cornerstone ${ }^{(4)}$. Antepartum EFM is one of the commonly used methods for the evaluation of fetal oxygenation. A properly applied EFM contributes significantly to early detection of fetal hypoxia, and thus helps to prevent fetal mortality and healthier feto-maternal outcomes ${ }^{(5)}$. As proposed in the literature, main purpose of fetal surveillance is to detect fetal hypoxia and acidosis, and therefore help to prevent perinatal mortality/morbidity, optimize outcomes and minimize medicolegal risks ${ }^{(6,7)}$. Advantages of EFM include lower intrapartum death rates, better Apgar scores, and the assurance of well-being in the high-risk fetus ${ }^{(8)}$.

The most common method of antepartum fetal surveillance assessment by FHR interpretation is the nonstress test (NST) ${ }^{(4)}$. NST provides fetal surveillance in the antepartum and intrapartum periods that would help to decrease the incidence of birth asphyxia with the lowest possible rate of unnecessary obstetrical intervention ${ }^{(9,10)}$. The NST consists of monitoring only, and the fetus is not challenged or stressed by uterine contractions. Therefore, it is noninvasive, painless, and believed to be without risk to mother or fetus ${ }^{(11)}$.

The NST is typically performed in the semiFowler's, semi-Fowler's left lateral, sitting or side lying positions ${ }^{(11,12)}$, in an office or a hospital setting during daytime hours as a routine screening test. Women are requested to be nonfasting and to have refrained from recent smoking which can adversely affect test results. The FHR is monitored by the placement of a fetal heart rate and a uterine contraction probe on maternal abdomen with one or two belts. The usual 20 minutes of monitoring may be extended to 40 minutes if the fetus is in a sleep cycle, or when necessary. The woman records each fetal movement by the use of self-operated markers. A nonreactive (abnormal) NST reactivity indicates lack of sufficient FHR accelerations over a 40-minute period. Again, it is important to take into account the gestational age of the fetus. Both fetal movement and the amplitude of the FHR accelerations increase with gestational age ${ }^{(12)}$.

Most commonly, nurses perform and interpret nonstress test results; thus, they have a responsibility to ensure that assessment of fetal well-being is as accurate and effective as possible. Nursing responsibilities in EFM include giving information, evaluation of maternal status, observation, interpretation of results, and proper intervention according to EFM data ${ }^{(12,13)}$. The nurse may also report the findings to the family physician/obstetrician for further interventions. The nurse may also use this opportunity to assess learning needs of the mother concerning the importance of fetal movements and provide information and training ${ }^{(12)}$.

Recently various alternative positions for NST applications have been proposed, such as walking or sitting positions. Maternal perception of fetal movements has been found to be highest in the reclining position, but the walking and sitting positions have resulted in a shorter period to obtain two accelerations of FHRs ${ }^{(12)}$. Some suggest that after 32 gestational weeks, lateral recumbent or sitting positions may be more acceptable for the patients at least to avoid inducing supine hypotension or maternal and possibly fetal discomfort ${ }^{(4)}$.

There are limited number of studies related to maternal position in NST in the literature. In this study, we aimed to investigate the effects of different maternal positions on reactivity of the NST, maternal blood pressure and heart rate.

\section{MATERIAL and METHODS}

We performed this experimental study in the 
Obstetric and Gynaecologic Clinic in an Education and Research Hospital, located in Ankara/Turkey, between December 2014 and April 2015. Ethical approval was received from the Institutional Board. The sample of this study consisted of the pregnant women in their 34-40 gestational weeks, who came for routine NST evaluation and accepted to participate in the study during the study period. The participants were informed about the study, and also required to read and sign the informed consent form. Sample size was calculated to be at least 63 pregnant women for each group within the $95 \%$ confidence interval, using power and sample size program. We have prepared a table according to NST position and gestational weeks. At least 9 pregnant women for each gestational week were assigned in each group. We placed pregnant women in the queue to the corresponding group according to this table. We evaluated 63 pregnant women in sitting position, 91 in semi-Fowler's position and 89 in semi-Fowler's left lateral position during study time.

\section{Inclusion Criteria:}

- Low risk pregnant women aged between 18-40 years with a single fetus, and available fetal biometric measurements and amniotic fluid consistent with gestational age of 34-40 gestational weeks and applying for NST evaluation

- Pregnants in non-fasting state who quitted smoking recently

\section{Exclusion Criteria:}

- Smoking and alcohol use in pregnancy

- Fetal anomaly findings in ultrasonography

- High body temperature before NST, maternal systemic diseases and drug use.

\section{Forms used in the study:}

In the study data were collected using the questionnaire form containing the socio-demographic and obstetrics characteristics of the women and "NST Form".

The socio-demographic and obstetric characteristics questionnaire consisting of 20 questions about age, education, employment status, history and health problems in previous and current pregnancy was developed by the researchers.

We prepared a NST Form by using definitions updated by the Eunice Kennedy Shriver National Institute of Child Health and Human Development (NICHD) in 2008. This NST form contains information about maternal position, onset, and termination times, maternal blood pressure and heart rate at the beginning and 10 minutes after, body temperature before test, fetal movements felt by the mother, contractions, basal FHR, variability, accelerations, decelerations, and the time period when test reactivity was achieved.

\section{Application of the study:}

- The NST applications were all made by researchers.

- Following positions were used for performing NST: 1) Semi-Fowler, 2) Semi- Fowler left lateral and 3) Sitting

- As previously described, pregnants were randomly assigned to the groups by following the position table in accordance with gestational age.

- NST application were made

- If a pregnant woman didn't accept the proposed position, she was excluded from the study.

- NST results were interpreted by researchers and an obstetrician, and saved to the NST form.

\section{Data Analysis:}

The data collected from 243 pregnant women were analysed using Statistical Package for the Social Sciences (SPSS) 15.0 for Windows Evaluation Version. Pregnant women in each position group were divided into two separate groups: one group consisted of gravidas in 34-37 gestational weeks, the other group consisted of gravidas in 38-40 gestational weeks. Statistical analyses were done according to position groups and gestational weeks in each group. For descriptive statistics, frequencies, arithmetic mean, standard deviation, median, percentile, minimum and maximum values were used. For the statistical comparison of the continuous variables, one-way variance analysis (One way ANOVA), and $t$ test in independent groups were used. For the statis- 
tical comparison of the discrete variables, chi-square or Fisher's exact chi-square test were used. McNemar's test was used in the dependent group. For the linear relationships between variables, Spearman correlation test was used. $\mathrm{p}<0.05$ value was considered to be statistically significant.

\section{RESULTS}

Mean age of pregnant women was 30.1 \pm 4.8 (19-40) years, $60.1 \%(n=146)$ of them had university and higher education, and $40.3 \%$ of them were employed. Primigravidas consisted of $42.8 \%(\mathrm{n}=104)$, nulliparas $54.3 \%(\mathrm{n}=132)$ of the study population. Out of 136 pregnant women, $56.0 \%$ of them were in 34-37 gestational weeks (Group 1), and others (44.0\%) were in their 38-40 gestational weeks (Group 2).

Most $(81.5 \%, \mathrm{n}=198)$ of the total NST results demonstrated NST reactivity. In $77.2 \%(n=105)$ of the pregnants in their 34-37 gestational weeks, and $86.9 \%(n=93)$ of the pregnants in their gestational 38-40 weeks demonstrated NST reactivities. Statistics showed that, regardless of the position, reactivity was

Table 1. NST results according to the gestational weeks and maternal position.

\begin{tabular}{|c|c|c|c|c|c|}
\hline $\begin{array}{l}\text { Gestational } \\
\text { weeks }\end{array}$ & & Reactive & $\begin{array}{l}\text { Non- } \\
\text { reactive }\end{array}$ & $\begin{array}{c}\text { Fetal } \\
\text { tachycardia }\end{array}$ & Total \\
\hline $\begin{array}{l}34-37 \\
\text { gestational week }\end{array}$ & n $\%$ & $105(77,2)$ & $24(17,7)$ & $7(5,1)$ & $\begin{array}{c}136 \\
(100)\end{array}$ \\
\hline $\begin{array}{l}38-40 \\
\text { gestational week }\end{array}$ & $\mathrm{n} \%$ & $93(86,9)$ & $13(12,2)$ & $1(0,9)$ & $\begin{array}{c}107 \\
(100)\end{array}$ \\
\hline Total & n $\%$ & $198(81,5)$ & $37(15,2)$ & $8(3,3)$ & $\begin{array}{c}243 \\
(100)\end{array}$ \\
\hline$*$ Test / p & & \multicolumn{4}{|c|}{$5,109^{a} / 0,078$} \\
\hline Positions & & Reactive & $\begin{array}{l}\text { Non- } \\
\text { reactive }\end{array}$ & $\begin{array}{c}\text { Fetal } \\
\text { tachycardia }\end{array}$ & Total \\
\hline Semi fowler & n $\%$ & $71(78,0)$ & $16(17,6)$ & $4(4,4)$ & $\begin{array}{c}91 \\
(100)\end{array}$ \\
\hline $\begin{array}{l}\text { Semi fowler left } \\
\text { lateral }\end{array}$ & $\mathrm{n} \%$ & $72(80,9)$ & $15(16,9)$ & $2(2,2)$ & $\begin{array}{c}89 \\
(100)\end{array}$ \\
\hline Sitting & $\mathrm{n} \%$ & $55(87,3)$ & $6(9,5)$ & $2(3,2)$ & $\begin{array}{c}63 \\
(100)\end{array}$ \\
\hline Total & n $\%$ & $198(81,5)$ & $37(15,2)$ & $8(3,3)$ & $\begin{array}{l}243 \\
(100)\end{array}$ \\
\hline$*$ Test / p & & & $2,866^{\mathrm{a}}$ & $\mathrm{s}^{\mathrm{a}} / 0,581$ & \\
\hline
\end{tabular}

* Pearson Ki-square not significantly different between the two groups ( $>0.05$ ) (Table 1).

We have found test results to be positive in semiFowler, semi-Fowler's left lateral and sitting positions in $78 \%(n=71), 80.9 \%(n=72)$ and $87.3 \%(n=55)$ of the pregnant women, respectively. There were no significant differences in NST reactivity between maternal positions regardless of gestational weeks ( $>0.05)$ (Table 1).

When a total of 198 reactive NST results were evaluated in 4 different time periods, $(0-5,6-10$, 11-15 and 16-20 minutes) time-to-reactivity in relation to maternal position did not reveal a statistically significant difference among groups $(\mathrm{p}>0.05)$. When the time-to-reactivity periods $(0-5 \mathrm{~min}, 0-10 \mathrm{~min}$, and 0-15 min) were compared independently from maternal positions, there was a statistically significant difference $(p<0,001)$.

Table 2. Time-to-reactivity periods according to maternal position.

\begin{tabular}{|c|c|c|c|c|c|c|}
\hline Time period & & $\begin{array}{l}\text { Semi } \\
\text { fowler }\end{array}$ & $\begin{array}{c}\text { Semi } \\
\text { fowler } \\
\text { left } \\
\text { lateral }\end{array}$ & Sitting & Total & *Test \\
\hline 0-5 minutes & n $\%$ & $\begin{array}{c}41 \\
(57.7)\end{array}$ & $\begin{array}{c}38 \\
(52.8)\end{array}$ & $\begin{array}{c}31 \\
(56.4)\end{array}$ & $\begin{array}{c}110 \\
(55.6)\end{array}$ & $2.697^{\mathrm{a}} 0.846$ \\
\hline $6-10$ minutes & n $\%$ & $\begin{array}{c}18 \\
(25.4)\end{array}$ & $\begin{array}{c}24 \\
(33.3)\end{array}$ & $\begin{array}{c}19 \\
(34.5)\end{array}$ & $\begin{array}{c}61 \\
(30.8)\end{array}$ & \\
\hline $11-15$ minutes & n $\%$ & $\begin{array}{c}10 \\
(14.1)\end{array}$ & $\begin{array}{c}8 \\
(11.1)\end{array}$ & $\begin{array}{c}4 \\
(7.3)\end{array}$ & $\begin{array}{c}22 \\
(11.1)\end{array}$ & \\
\hline $16-20$ minutes & n $\%$ & $\begin{array}{c}2 \\
(2.8)\end{array}$ & $\begin{array}{c}2 \\
(2.8)\end{array}$ & $\begin{array}{c}1 \\
(1.8)\end{array}$ & $\begin{array}{c}5 \\
(2.5)\end{array}$ & \\
\hline Total & n $\%$ & $\begin{array}{c}71 \\
(100)\end{array}$ & $\begin{array}{c}72 \\
(100)\end{array}$ & $\begin{array}{c}55 \\
(100)\end{array}$ & $\begin{array}{c}198 \\
(100)\end{array}$ & \\
\hline
\end{tabular}

Maternal position independent time-to-reactivity periods.

\begin{tabular}{|c|c|c|}
\hline & Total & Test/p ${ }^{* * *}$ \\
\hline 0-5 minutes & $\begin{array}{r}\text { n } \% 110(55,6) * 192,421^{\mathrm{a}} \\
\mathrm{p}<0,001\end{array}$ & \\
\hline 0-10 minutes & n \% $171(86,4)$ & $\begin{array}{l}* 40,890^{\mathrm{a}} \\
\mathrm{p}<0,001\end{array}$ \\
\hline $0-15$ minutes & n \% $193(97,5)$ & $* * \mathrm{p}=0,061$ \\
\hline $0-20$ minutes & n \% $198(100)$ & \\
\hline Total & n \% $198(100)$ & \\
\hline
\end{tabular}


When the time-to-reactivity periods between 0-15 and 0-20 minutes were compared independently from maternal position, there was no statistically significant difference $(\mathrm{p}>0,05)$ (Table 2$)$.

Table 3. Maternal perception of fetal movements and NST results according to maternal position.

\begin{tabular}{|c|c|c|c|c|c|c|c|c|}
\hline Maternal position & & Fetal movements & Reactive & Non-reactive & Fetal tachycardia & Total (n) & *Test & p \\
\hline Semifowler & $\begin{array}{l}\text { Yes } \\
\text { No }\end{array}$ & $\begin{array}{l}\mathrm{n} \\
\% \\
\mathrm{n} \\
\%\end{array}$ & $\begin{array}{c}67 \\
94,4 \\
4 \\
5,6\end{array}$ & $\begin{array}{c}11 \\
68,8 \\
5 \\
31,3\end{array}$ & $\begin{array}{c}4 \\
100 \\
0 \\
0\end{array}$ & $\begin{array}{c}82 \\
90,1 \\
9 \\
9,9\end{array}$ & $10,073^{a}$ & 0,66 \\
\hline Total & & $\begin{array}{l}\mathrm{n} \\
\%\end{array}$ & $\begin{array}{c}71 \\
100\end{array}$ & $\begin{array}{c}16 \\
100\end{array}$ & $\begin{array}{c}4 \\
100\end{array}$ & $\begin{array}{c}91 \\
100\end{array}$ & & \\
\hline Semifowler left lateral & $\begin{array}{l}\text { Yes } \\
\text { No }\end{array}$ & $\begin{array}{l}\mathrm{n} \\
\% \\
\mathrm{n} \\
\%\end{array}$ & $\begin{array}{c}69 \\
95,8 \\
3 \\
4,2\end{array}$ & $\begin{array}{c}10 \\
66,7 \\
5 \\
33,3\end{array}$ & $\begin{array}{c}2 \\
100 \\
0 \\
0\end{array}$ & $\begin{array}{c}81 \\
91 \\
8 \\
9\end{array}$ & $13,111^{\mathrm{b}}$ & 0,12 \\
\hline Total & & $\begin{array}{l}\mathrm{n} \\
\%\end{array}$ & $\begin{array}{c}72 \\
100\end{array}$ & $\begin{array}{c}15 \\
100\end{array}$ & $\begin{array}{c}2 \\
100\end{array}$ & $\begin{array}{c}89 \\
100\end{array}$ & & \\
\hline Sitting & $\begin{array}{l}\text { Yes } \\
\text { No }\end{array}$ & $\begin{array}{l}\mathrm{n} \\
\% \\
\mathrm{n} \\
\%\end{array}$ & $\begin{array}{c}53 \\
96,4 \\
2 \\
3,6\end{array}$ & $\begin{array}{c}5 \\
83,3 \\
1 \\
16,7\end{array}$ & $\begin{array}{c}2 \\
100 \\
0 \\
0\end{array}$ & $\begin{array}{c}60 \\
95,2 \\
3 \\
4,8\end{array}$ & $2,129^{c}$ & 0,345 \\
\hline Total & & $\begin{array}{l}\mathrm{n} \\
\%\end{array}$ & $\begin{array}{c}55 \\
100\end{array}$ & $\begin{array}{c}6 \\
100\end{array}$ & $\begin{array}{c}2 \\
100\end{array}$ & $\begin{array}{c}63 \\
100\end{array}$ & & \\
\hline
\end{tabular}

* Pearson ki-square

Table 4. Starting and 10 minutes blood pressure (BP) and heart beat values in different maternal positions.

\begin{tabular}{|c|c|c|c|c|c|c|}
\hline & & \multicolumn{3}{|c|}{ Position } & \multirow[b]{2}{*}{$*$ Test } & \multirow[b]{2}{*}{$\mathbf{p}$} \\
\hline & & $\begin{array}{c}\text { Semi fowler } \\
\mathbf{n}=91\end{array}$ & $\begin{array}{c}\text { Semi fowler left lateral } \\
n=89\end{array}$ & $\underset{n=63}{\text { Sitting }}$ & & \\
\hline \multirow{4}{*}{ Systolic BP (mm/hg) } & $\begin{array}{l}\text { Starting } \\
10 \text { minutes }\end{array}$ & $\begin{array}{c}104,8 \pm 11,2 \\
99,2 \pm 12,6\end{array}$ & $\begin{array}{l}104,0 \pm 11,9 \\
100,3 \pm 11,9\end{array}$ & $\begin{array}{l}104,3 \pm 13,1 \\
98,2 \pm 12,1\end{array}$ & $0,867^{\mathrm{a}}$ & 0,421 \\
\hline & $\begin{array}{l}* \text { difference } \\
* * \text { Min-Max } \\
* * * \% 95 \text { CI }\end{array}$ & $\begin{array}{c}5,6 \pm 14,9 \\
(-40)-35 \\
2,5-8,7\end{array}$ & $\begin{array}{c}3,6 \pm 12,1 \\
(-30)-30 \\
1,1-6,2\end{array}$ & $\begin{array}{c}6,1 \pm 9,5 \\
(-10)-35 \\
3,7-8,5\end{array}$ & & \\
\hline & $\begin{array}{l}\text { Starting } \\
10 \text { minutes }\end{array}$ & $\begin{array}{c}67,2 \pm 9,6 \\
66,7 \pm 10,4\end{array}$ & $\begin{array}{c}67,3 \pm 9,2 \\
66 \pm 8,9\end{array}$ & $\begin{array}{c}66,3 \pm 10,2 \\
63,8 \pm 7,4\end{array}$ & $0,677^{\mathrm{b}}$ & 0,509 \\
\hline & $\begin{array}{l}\text { difference } \\
\text { Min-Max } \\
\text { \%95 CI }\end{array}$ & $\begin{array}{c}0,5 \pm 11,3 \\
(-30)-40 \\
(-1,8)-2,9\end{array}$ & $\begin{array}{c}1,2 \pm 9,9 \\
(-30)-30 \\
(-0,8)-3,3\end{array}$ & $\begin{array}{c}2,5 \pm 9,6 \\
(-20)-40 \\
0,1-4,9\end{array}$ & & \\
\hline Diastolic BP (mm/hg) & $\begin{array}{l}\text { Starting } \\
10 \text { minutes } \\
\text { difference }\end{array}$ & $\begin{array}{c}93,5 \pm 13,3 \\
94,1 \pm 11,4 \\
-0,5 \pm 8,5\end{array}$ & $\begin{array}{l}89,2 \pm 13 \\
93 \pm 12,5 \\
-3,7 \pm 8,1\end{array}$ & $\begin{array}{c}89,9 \pm 10,1 \\
91,2 \pm 10,5 \\
-1,3 \pm 7,7\end{array}$ & $3,665^{\mathrm{c}}$ & 0,027 \\
\hline Heart Beat (beat/minute) & $\begin{array}{l}\text { Min-Max } \\
\% 95 \text { CI }\end{array}$ & $\begin{array}{l}(-24)-20 \\
(-2,3)-1,1\end{array}$ & $\begin{array}{l}(-28)-15 \\
(-5,4)-(-2)\end{array}$ & $\begin{array}{l}(-38)-16 \\
(-3,3)-0,6\end{array}$ & & \\
\hline
\end{tabular}

*One way ANOVA, **Minimum-Maximum, ***\%95 Confidence interval 
During NST, $91.8 \%(n=223)$ of pregnants felt fetal movements. In 198 reactive NST's, 95.5\% ( $\mathrm{n}=189)$, and in 37 non-reactive NST's, 70.3\% $(n=26)$ of pregnant women felt the fetal movements. Fetal movements were felt by the mothers in $100 \%$ of 8 NST's where fetal tachycardia was recorded. Predictability rates of correct maternal perception of fetal movements in semi-Fowler's, semi-Fowler's left lateral, and sitting positions (reactive: movement $(+)$, nonreactive: movement $(-)$, fetal tachycardia: movement $(+)$ were found to be $83.5,85.4$, and $88.9 \%$, respectively. In sitting position, perception of the fetal movements by the pregnants was higher when compared to other positions, however, there was no statistically significant difference in NST reactivity/nonreactivity among the positions $(\mathrm{p}>0.05)$ (Table 3$)$.

We have not found a statistically significant difference in maternal perception of fetal movement and NST reactivity/nonreactivity according to the gestational weeks (between Group 1 and Group 2) (p>0.05). Any significant difference was not found in fetal baseline heart rates regarding the maternal position among gestational age groups of 34-37 and 38-40 weeks ( $\mathrm{p}>0.05)$.

According to different maternal positions, maternal systolic, diastolic blood pressure levels between baseline and at 10 minutes were not significantly different $(p>0.05)$. Maternal heart rate values however, were significantly different in semi Fowler's left lateral position $(\mathrm{p}=0.027)$ (Table 4).

\section{DISCUSSION}

Maternal positions, such as lateral recumbency, lateral tilts, semi-Fowler's, semi-Fowler's with tilts, and sitting have been suggested for NST. These positions optimize uterine perfusion and fetal heart rate patterns and prevent maternal hypotension ${ }^{(11,12,14,15)}$. Since supine hypotension has been reported in previous studies, we have not included a maternal supine position in our study groups.

In our study, in sitting position NST reactivity was found to be higher than the other positions without any statistically significant intergroup difference $(p>0.05)$. In study of Cito et al. ${ }^{(16)}$ since in NST tests fetal reactivity was observed at an earlier stage in sitting position or during walking, they proposed using these NST positions. Aluş et al. ${ }^{(14)}$ investigated the effects of sitting up, semi-Fowler's, supine and supine left positions on fetal reactivity and time-toreactivity in NSTs performed with four different groups in 408 women, and found statistically significant results, in that supine position yielding the lowest (69\%) and semi- Fowler's position the highest reactivity $(85.3 \%)$ rates. Kaur et al. ${ }^{(17)}$ did not observe significant difference in reactivity of NST between left lateral and sitting position. Moffatt et al. ${ }^{(15)}$ compared semi-Fowler's position with semi-Fowler's left or right positions in their evaluation of 738 NST recordings of 573 pregnant women between 32.-42. gestational weeks and found no clinically or statistically significant differences as for NST reactivities between the three groups, with an overall reactivity of 96.37 percent.

In order to get a reliable reactive NST result, a 20-minute-application is generally accepted as sufficient ${ }^{(12,14)}$. However, due to the increased number of patients and thus relatively limited number of electrotococardiograms and technical personnel, 20minute-application seem to cause long waiting periods for the pregnant women in the queue for NST. In our study we have not encountered a statistically significant difference in reactivity rates in relation to gestational weeks and maternal monitoring positions. When we evaluated the NST results in 4 time periods (0-5, 6-10, 11-15 and 16-20 minutes) independent of the position, we found statistically significant differences in time to reactivity between $0-5,0-10,0-10$ and $0-15$ minutes $(\mathrm{p}<0.001)$. There was no significant difference between 0-15 minutes and 0-20 minutes regarding the time to reactivity $(\mathrm{p}>0.05)$, which makes us to think that 15 minutes could be sufficient for a NST application. A randomized study of 108 patients with singleton pregnancies at their 32. to 42 . gestational weeks who had undergone NST reactivity tests in semi-Fowler's or left lateral recumbent positions revealed that the semi-Fowler's position was a superior position for conducting a NST within a short period, which could decrease the need for prolonged monitoring and lead to a more time-effective evalua- 
tion of patients at risk ${ }^{(18)}$. Cito et al. ${ }^{(16)}$ found that the duration of NST reactivities in the reclining position (defined as the time taken to record the three large accelerations) were comparable, however it was significantly shorter in the sitting position or during walking with the progression of pregnancy. Kaur et al. ${ }^{(17)}$ showed that NST performed in the left lateral position significantly required less time to achieve reactivity as compared to sitting position. Aluş et al. (14) could not find statistically significant differences among the four groups according to time to detect reactivity, supine position causing the lowest reactivity in tandem with physical discomfort such as back pain and difficulty in breathing in corroboration with previous literature.

Overall maternal perception of fetal movement rate in our study was found to be $95.5 \%$ in all reactive NSTs. Correct perception rate of fetal movements in sitting position was higher, although not statistically significant. When NST reactivity and maternal perception of fetal movements was evaluated according to maternal positions and gestational weeks, a statistically significant difference could not be found. Cito et al. ${ }^{(16)}$ reported that the number of fetal movements perceived by the mother was greater in the reclining position than in sitting position or walking.

In our study, as Friedman et al. ${ }^{(19)}$ also previously reported, there was no statistically significant difference in baseline FHRs in all gestational weeks regarding maternal position. Also Cito et al. ${ }^{(16)}$ concluded that baseline FHR did not significantly change with maternal position.

We have not encountered a significant difference in 0 and 10 minute values of maternal systolic and diastolic blood pressures regarding the maternal position $(p>0.05)$, but we noted a significant difference in maternal heart rate regarding the maternal position $(p=0.027)$. Indeed, heart rate values in the semiFowler's left lateral position were significantly less than the sitting position after 10 minutes. We found only one article in the literature evaluating maternal blood pressure during NST ${ }^{(15)}$, and there are no studies evaluating maternal heart rate during NST to the best of our knowledge. Moffatt et al. (15) suggested using laterally tilted semi-Fowler's positions, rather than semi-Fowler 's positions, to refrain from supine hypotensive syndrome symptoms such as nausea, vertigo, dizziness in semi-Fowler's positions, although their blood pressure recordings were recorded as normal.

Accurate evaluation of electronic fetal monitoring and appropriate interventions when necessary should be a basic skill of midwives and nurses working in obstetric services. Midwives and nurses usually leave evaluation to doctors after acquiring EFM results. They should be given more training and practice opportunities, which would help them to make more independent decisions and take more responsibility, helping more patients in shorter time ${ }^{(5,13)}$.

\section{CONCLUSIONS}

When the literature and our study results are evaluated, we believe that a specific position to all pregnant women in order to increase the reactivity of NST will not be feasible at the moment. However, NST applications at semi-Fowler's left lateral and sitting positions seem to be more appropriate in order to get results in the most comfortable position for the pregnant women.

Our study results did not show a statistically significant difference between 15 and 20 minute- NST applications as for NST reactivity, making us think that 15 minute-applications may be sufficient for NST evaluation.

A NST application in optimal conditions would prevent unnecessary waiting periods in outpatient clinics, uncomfortable conditions for pregnant women, further unnecessary examinations and evaluations, unjust decisions for hospitalization and deliveries, unnecessary costs and use of resources.

Positioning pregnants for NST is a very simple procedure, which help achievement of better and faster results. Pregnant women tend to feel the positions where their fetuses are more active, therefore asking their cooperation would help health personnel to make better decisions for maternal position during NST.

Studies from multicenter studies may provide additional evidence on the subject. 


\section{Limitations of the study:}

Smoking and/or alcohol use during pregnancy or exposure as a passive smoker have been determined according to self reports of the women.

In our clinic, routine NST applications are made in semi-Fowler's, semi-Fowler's left or right lateral positions. Some pregnant women didn't accept sitting position (thinking it is out of routine practice) for NST. These pregnant women were excluded from the study and we evaluated the pregnant women in sitting ( $n=63)$, semi Fowler's ( $n=91)$, and semi -Fowler's left lateral positions $(n=89)$ during our study period.

\section{REFERENCES}

1. Kinas MG, Demircan Sezer S, Yuksel H, Odabasi AR, Ture $\mathrm{M}$. The role of fetal movement amount on predicting the nonstress test results. Journal of Turkish Society of Obstetrics and Gynecology. 2011;8(4):238-43. https://doi.org/10.5505/tjod.2011.45822

2. Çiçek N, Akyürek C, Çelik Ç, Haberal A. Kadın Hastalıkları ve Doğum Bilgisi [Obstetrics and Gynecology Textbook]. Güneş. İstanbul, 2006; p. 239. In Turkish

3. Çorbacioğlu Kara A. Antepartum fetal monitoring. In: Has R. (Translation Editor). Fetal Heart Rate Monitoring (Editors: Freeman RK, Garite TJ, Nageotte MP). Nobel, 2015; p. 181202.

4. Esin $\mathrm{S}$. Factors that increase reactivity during fetal nonstress testing. Current Opinion in Obstetrics and Gynecology. 2014;26(2):61-6. https://doi.org/10.1097/GCO.0000000000000050

5. Demir N, Okumuş H, Aluş Tokat M. The effect of EFM education program on midwifes and nurses' knowledge and interpretation skills. Dokuz Eylül University Nursing Journal. 2011;4(2):63-6. https://dspace.deu.edu.tr/xmlui/handle/12345/4585

6. Miller DA, Miller LA. Electronic fetal heart rate monitoring: applying principles of patient safety. American Journal of Obstetrics \& Gynecology. 2012;206(4):278-83. https://doi.org/10.1016/j.ajog.2011.08.016

7. Kiettisanpipop P, Phupong V. Intrapartum and neonatal outcome of screening non-stress test (NST) compared with no screening NST in healthy women at 40-40 (+6) weeks of gestation. The Journal of Obstetrics and Gynaecology Research. 2015;41(1):50-4. https://doi.org/10.1111/jog.12497

8. McConaughey E. Fetal Evaluation and Clinical Applications. In: Angelini DJ, Lafontaine D. (editors). Obstetric Triage and Emergency Care Protocols. Springer Publishing Company. 2013; p.97-109.

9. Liston R, Sawchuck D, Young D. Fetal health surveillance: Antepartum and intrapartum consensus guideline. Journal of Obstetrics and Gynaecology Canada. 2007;29(9):3-4. https://doi.org/10.1016/S1701-2163(16)32615-9

10. Aktulay A, Engin Üstün Y, Yapar Eyi E, Yörük Ö, Hançerlioğulları N, Mollamahmutoğulları L. Evaluation of non-reactive NST at low risk pregnancy. The Journal of Gynecology-Obstetrics and Neonatology 2013;10(37):1542-4.

11. McKinney ES, James SR, Murray SS, Nelson K, Ashwill J. Maternal-Child Nursing E-Book. Fifth Edition, Elsevier 2018; (Last Accessed Date: November 9, 2017), p. 281. https://books.google.com.tr/books?isbn $=0323478344$

12. Davidson M, London M, Ladewig P. Old's maternal-newborn nursing\&women's health across the lifespan. Ninth edition, Harlow, 2014; p. 548-50.

13. Aluş Tokat M. Antepartum elektronic fetal monitoring. In: Aluş Tokat M. (editor). Gebelikte ve Doğum Eyleminde Elektronik Fetal İzlem [Electronic fetal monitoring in antepartum and intrapartum]. Deomed, İstanbul; 2013. p. 37-50. In Turkish

14. Aluş M, Okumuş H, Mete S, Güçlü S. The effects of different maternal positions on nonstress test: an experimental study. Journal of Clinical Nursing. 2007;16(3):562-8. https://doi.org/10.1111/j.1365-2702.2006.01570.x

15. Moffatt FW, van den Hof M. Semi-Fowler's positioning, lateral tilts, and their effects on nonstress tests. Journal of Obstetric, Gynecologic \& Neonatal Nursing. 1997;26(5):551-7. https://doi.org/10.1111/j.1552-6909.1997.tb02158.x

16. Cito G, Luisi S, Mezzesimi A, Cavicchioli C, Calonaci G, Petraglia F. Maternal position during non-stress test and fetal heart rate patterns. Acta Obstetricia et Gynecologica Scandinavica. 2005;84(4):335-8. https://doi.org/10.1111/j.0001-6349.2005.00644.x

17. Kaur VS, Saha PK. A comparative study to assess the effect of different maternal position on reactivity and time consumption for non stress test. Nursing and Midwifery Research Journal. 2015;11(4):145-52.

18. Nathan EB, Haberman S, Burgess T, Minkoff H. The relationship of maternal position to the results of brief nonstress tests: a randomized clinical trial. American Journal of Obstetrics \& Gynecology. 2000;182(5):1070-2.

https://doi.org/10.1067/mob.2000.105443

19. Friedman M, Divon MY, Zimmer EZ, Goldstein I, Peretz BA, Paldi E. Nonstress test in standing and lying women. Early Human Development. 1983;8(3-4):317-22. https://doi.org/10.1016/0378-3782(83)90014-2 